\title{
Effect of Sports and Media on Nutritional Habits in Individuals who Attend Sports Centers
}

\section{Ayse Humeyra Islamoglu'*, Zehra Margot Celik ${ }^{1}$, Izel Aycan Basoglu${ }^{1}$, Zubeyde Celik², Meltem Nazli ${ }^{3}$, Ozlem Deniz Tasbas $^{4}$, Duygu Acan ${ }^{3}$ and Fatma Esra Gunes ${ }^{1}$}

${ }^{1}$ Department of Nutrition and Dietetics, Marmara University, Faculty of Health Sciences, Turkey

${ }^{2}$ Postgraduate Student, Private Ilgi Hospital, Marmara University Sports Health Sciences, Turkey

${ }^{3}$ Graduate Student, Department of Nutrition and Dietetics, Marmara University, Faculty of Health Sciences, Turkey

${ }^{4}$ Pirilla Nutrition Consultancy, Turkey

*Corresponding Author: Ayse Humeyra Islamoglu, Department of Nutrition and Dietetics, Marmara University, Faculty of Health Sciences, Turkey.

Received: October 23, 2019; Published: November 04, 2019

DOI: $10.31080 /$ ASNH.2019.03.0520

\begin{abstract}
The aim of this study was to investigate the effect of sports and media on individuals' nutritional habits. This study is a crosssectional descriptive study and it was conducted with women $(n=329)$ and men $(n=328)$ volunteers that were aged between 18-45 years and who attend sports centers in Istanbul/Turkey from February 2017 to May 2019. This study's data were obtained from a questionnaire and an anthropometric measurement record of participants. Data were analyzed using SPSS 23 (Statistical Package for the Social Sciences). Results were evaluated at 95\% confidence interval and $\mathrm{p}<0.05$ significance level. The results showed that women followed more diet and health related pages than men $(\mathrm{p}=0.0001)$. Women were changing their diet according to the information obtained from social media more than men $(\mathrm{p}=0.024)$. According to the results of the food frequency questionnaire, those who follow health and diet related pages on social media consume significantly more dairy products $(\mathrm{p}=0.031)$, wholemeal bread $(\mathrm{p}=0.0001)$, fruit $(\mathrm{p}=0.046)$ and consume significantly less white bread $(\mathrm{p}=0.0001)$ and pasta-rice $(\mathrm{p}=0.046)$. When the participants were separated according to their social media page follow-up status, no statistically significant difference was found between their body weight perceptions and their desire to lose or gain weight according to their BMIs ( $p>0.05$ ). Our research shows that individuals who do sports mostly obtain their nutritional information from the internet. Nowadays, the widespread use of the internet, and especially social media and the high level of nutritional information pollution these channels produce, may lead to misinformation. Future research should consider how to more effectively use social media to support individuals in making healthier choices in terms of healthy living and nutrition.

Keywords: Sport; Media; Social Media; Nutrition; Nutritional Habits
\end{abstract}

\section{Introduction}

Lifestyle modifications, including positive changes in nutritional behaviors can develop a helthier life by significantly reducing the possible chronic diseases in further life [1]. With the developing technology in our age, the media can reach the masses in a short time and affect the behaviors of individuals in many areas [2]. A variety of media have been used to deliver mass-reach health campaigns, like radio, television, advertising on billboards [3]. and recently, online social media networks [4]. In our country where the literacy rate is $93 \%$, individuals access information about health, mostly use health programs, social media, newspapers, magazines, blogs, web pages and television [2].

Social media and modern technology have opened a new era in how health-related information is transmitted and sought by users [5]. The number of information shared in the media on issues such as nutrition, diet and healthy living is increasing day by day.
This information in the media may be inaccurate and may cause individuals to gain the wrong habits of nutrition [6].

Women give more importance to the appearance of thinness, while men give more importance to the muscular body structure [7]. Being thins is often emphasized in the media, and this makes women successful, attractive and socially accepted [8]. It is known that women and children change their eating habits by being more affected by the media than men [9].

Nowadays, sports have become a part of social life. The positive effect of exercise on individuals has led people to engage in sports and recently there has been an increase in the number of women engaged in active sports [10]. Among physically active individuals, body perception is more important in women than in men [7]. Body perception is related to how people perceive their own bodies and change according to the age and society. The beauty con- 
cept offered is the delicacy for women and the muscular structure for men. For this reason, fasting diets, unhealthy diets and extreme sports are observed in individuals with negative body perception [11]. At the same time, self-esteem and eating habits increase individuals' tendency to physical activity [12].

The aim of this study was to investigate the effect of sports and media on individuals' nutritional habits.

\section{Materials and Methods}

Research model and study group

This study is a cross-sectional descriptive study and it was conducted with women $(n=329)$ and men $(n=328)$ volunteers that were aged between 18-45 years and who attend sports centers in Istanbul/Turkey from February 2017 to May 2019. Written informed consent was taken from all participants at the beginning of the study. Ethics committee approval was obtained from Marmara University Faculty of Medicine Clinical Research Ethics Committee on 06.01.2017 with protocol number 09.2017.032.

\section{Data collection}

For anthropometric measurements of participants "TANITA BC 418 MA" and a standard measuring tape was used by the researchers. Body Mass Indexes (BMI) were divided into groups according to the classification determined by the World Health Organization [13].

A questionnaire and an anthropometric measurement record were used for data collection. Prior to the development of the questionnaire, a literature review was conducted by the researchers. The questionnaire is consisted of 12 questions about the demographic characteristics of the participants, 11 questions about physical activity and 31 questions about the nutritional habits.

\section{Data analysis}

All data were analyzed using SPSS 23 (Statistical Package for the Social Sciences). Chi-square test was used for analysis. Qualitative data were evaluated as number (n) and percentage (\%). The data obtained from individuals were shown as arithmetic mean (x), standard deviation (S), min and max values. Results were evaluated at $95 \%$ confidence interval and $p<0.05$ significance level.

\section{Results}

The study was conducted between February 2017 and May 2019 with 657 individuals aged between 18 and 45 years.

$50.1 \%(\mathrm{n}=329)$ of the individuals were female and $49.9 \%(\mathrm{n}=$ 328) were male. All general characteristics of the participants are shown in table 1.

\begin{tabular}{|l|c|c|}
\hline & Women n (\%) & Men n (\%) \\
\hline Age Groups (years) & & \\
\hline $18-25$ & $150(22.8)$ & $207(31.5)$ \\
\hline $26-35$ & $81(12.3)$ & $94(14.3)$ \\
\hline $36-45$ & $97(14.8)$ & $27(4.1)$ \\
\hline Education Levels & & \\
\hline Not Literate & $1(0.2)$ & $1(0.2)$ \\
\hline Literate & $4(0.6)$ & $2(0.3)$ \\
\hline Primary School & $28(4.3)$ & $3(0.5)$ \\
\hline Middle School & $24(3.7)$ & $5(0.8)$ \\
\hline High School & $103(15.7)$ & $75(11.4)$ \\
\hline University & $162(24.7)$ & $233(35.5)$ \\
\hline Graduate & $7(1.1)$ & $9(1.4)$ \\
\hline Marital Status & & \\
\hline Married & $132(20.1)$ & $30(4.6)$ \\
\hline Single & $197(30.0)$ & $298(45.3)$ \\
\hline Alcohol Consumption & & \\
\hline Yes & $28(4.3)$ & $92(14.0)$ \\
\hline No & $301(45.8)$ & $236(35.9)$ \\
\hline Smoking & & \\
\hline Yes & $55(8.4)$ & $118(18.0)$ \\
\hline No & $274(41.7)$ & $210(32.0)$ \\
\hline
\end{tabular}

Table 1: General characteristics of the participants.

\begin{tabular}{|l|c|c|c|}
\hline & \multicolumn{2}{|c|}{ X \pm SD } & \\
\hline & $\begin{array}{c}\text { Women } \\
(\mathbf{n = 3 2 9})\end{array}$ & $\begin{array}{c}\text { Men } \\
(\mathbf{n = 3 2 8})\end{array}$ & \\
\hline Height (cm) & $163.6 \pm \mathbf{6 . 2}$ & $178.0 \pm 7.3$ & \\
\hline Body weight (kg) & $64.7 \pm 12.2$ & $76.3 \pm 12.7$ & \\
\hline $\begin{array}{l}\text { Waist circumference } \\
\text { (cm) }\end{array}$ & $77.2 \pm 13.0$ & $79.9 \pm 11.3$ & \\
\hline $\begin{array}{l}\text { Exercise duration } \\
\text { per week (hour) }\end{array}$ & $3.9 \pm 2.4$ & $4.6 \pm 2.7$ & \\
\hline BMI Categories & $\mathrm{n}(\%)$ & $\mathrm{n}(\%)$ & Total n (\%) \\
\hline Thin & $19(2.8)$ & $5(0.8)$ & $24(3.6)$ \\
\hline Normal & $193(29.3)$ & $237(36.1)$ & $430(65.4)$ \\
\hline Overweight & $79(12.0)$ & $70(10.7)$ & $149(22.7)$ \\
\hline Obese & $38(5.9)$ & $16(2.4)$ & $54(8.3)$ \\
\hline Sports Branch & $\mathrm{n}(\%)$ & $\mathrm{n}(\%)$ & Total n (\%) \\
\hline Pilates & $54(8.2)$ & $7(1.1)$ & $61(9.3)$ \\
\hline Kick-box & $3(0.5)$ & $16(2.4)$ & $19(2.9)$ \\
\hline Swimming & $29(4.4)$ & $30(4.6)$ & $59(9.0)$ \\
\hline Fitness & $171(26.0)$ & $206(31.4)$ & $377(57.4)$ \\
\hline $\begin{array}{l}\text { Others (yoga, } \\
\text { spinning, dance ect.) }\end{array}$ & $72(11.0)$ & $69(10.4)$ & $141(21.4)$ \\
\hline
\end{tabular}

Table 2: Anthropometric measurements and sports status of the participants.

Anthropometric measurements and general information about sporting status of the participants were shown in table 2. It was ob- 
served that most of the participants $(65.5 \%)$ had normal BMI and most of the participants (57.4\%) preferred fitness in the gym.

\begin{tabular}{|c|c|c|c|c|}
\hline & $\begin{array}{c}\text { Women } \\
\text { n (\%) }\end{array}$ & $\begin{array}{c}\text { Men } \\
\text { n (\%) }\end{array}$ & $\begin{array}{l}\text { Total } \\
\text { n (\%) }\end{array}$ & $\mathbf{p}$ \\
\hline \multicolumn{5}{|l|}{$\begin{array}{l}\text { Source of nutritional } \\
\text { information }\end{array}$} \\
\hline Television & $31(5.4)$ & $27(4.7)$ & $58(10.1)$ & \multirow{6}{*}{0.612} \\
\hline $\begin{array}{l}\text { Books-newspa- } \\
\text { pers-magazines }\end{array}$ & $20(3.5)$ & $27(4.7)$ & $47(8.1)$ & \\
\hline $\begin{array}{l}\text { Internet-social } \\
\text { media }\end{array}$ & $120(20.8)$ & $\begin{array}{c}178 \\
(30.8)\end{array}$ & $298(51.6)$ & \\
\hline Doctor & $25(4.3)$ & $25(4.3)$ & $50(8.7)$ & \\
\hline Dietitian & $51(8.8)$ & $44(7.6)$ & $95(16.5)$ & \\
\hline Others & $19(3.7)$ & $10(1.5)$ & $29(5.0)$ & \\
\hline Total & $266(46.1)$ & $\begin{array}{c}311 \\
(53.9) \\
\end{array}$ & $\begin{array}{c}577 \\
(100.0)\end{array}$ & \\
\hline \multicolumn{4}{|l|}{$\begin{array}{l}\text { Following health } \\
\text { and diet related pa- } \\
\text { ges on social media }\end{array}$} & \multirow{4}{*}{$0.0001^{* *}$} \\
\hline Yes & $191(29.2)$ & $\begin{array}{c}144 \\
(22.0)\end{array}$ & $335(51.1)$ & \\
\hline No & $137(20.9)$ & $\begin{array}{c}183 \\
(27.9)\end{array}$ & $320(48.9)$ & \\
\hline Total & $328(50.1)$ & $\begin{array}{c}327 \\
(49.9)\end{array}$ & $\begin{array}{c}655 \\
(100.0)\end{array}$ & \\
\hline \multicolumn{4}{|l|}{$\begin{array}{l}\text { Changing nutritional } \\
\text { behavior according } \\
\text { to information } \\
\text { obtained from social } \\
\text { media }\end{array}$} & \\
\hline Yes & $192(29.2)$ & $\begin{array}{c}146 \\
(22.2) \\
\end{array}$ & $338(51.4)$ & \multirow[t]{2}{*}{$0.024^{*}$} \\
\hline No & $137(20.9)$ & $\begin{array}{c}182 \\
(27.7) \\
\end{array}$ & $319(48.6)$ & \\
\hline
\end{tabular}

Table 3: Comparison of the effect of media on nutrition between genders.

The sources of nutritional information of men and women were found to be similar ( $p>0.05)$. Women followed more diet and health related pages than men ( $\mathrm{p}=0.0001)$. Women were changing their diet according to the information obtained from social media more than men ( $\mathrm{p}=0.024)$ (Table 3).

\begin{tabular}{|c|c|c|c|}
\hline & \multicolumn{3}{|c|}{$\begin{array}{l}\text { Following health and diet related } \\
\text { pages on social media }\end{array}$} \\
\hline & $\begin{array}{l}\text { Yes }(n=253) \\
\quad n(\%)\end{array}$ & $\begin{array}{l}\text { No }(n=404) \\
n(\%)\end{array}$ & $\mathbf{p}$ \\
\hline Dairy Products & & & \multirow{6}{*}{$0.031^{*}$} \\
\hline Never & $6(0.9)$ & $13(2.0)$ & \\
\hline Everyday & $233(35.5)$ & $188(28.6)$ & \\
\hline Every other day & $63(9.6)$ & $65(9.9)$ & \\
\hline Once in a week & $19(2.9)$ & $32(4.9)$ & \\
\hline Rare & $17(2.6)$ & $21(3.2)$ & \\
\hline White Meat & & & \multirow{6}{*}{0.578} \\
\hline Never & $18(2.7)$ & $9(1.4)$ & \\
\hline Everyday & $51(7.8)$ & $46(7.0)$ & \\
\hline Every other day & $134(20.4)$ & $130(19.8)$ & \\
\hline Once in a week & $107(16.3)$ & $104(15.8)$ & \\
\hline Rare & $28(4.3)$ & $30(4.6)$ & \\
\hline Red Meat & & & \\
\hline
\end{tabular}

\begin{tabular}{|c|c|c|c|}
\hline Never & $16(2.4)$ & $11(1.7)$ & \multirow{5}{*}{0.489} \\
\hline Everyday & $34(5.2)$ & $27(4.1)$ & \\
\hline Every other day & $118(18.0)$ & 103 (15.7) & \\
\hline Once in a week & $126(19.2)$ & $122(18.6)$ & \\
\hline Rare & $44(6.7)$ & $55(8.4)$ & \\
\hline \multicolumn{4}{|l|}{ Legumes } \\
\hline Never & $17(2.6)$ & $10(1.5)$ & \multirow{5}{*}{0.508} \\
\hline Everyday & $42(6.4)$ & $38(5.8)$ & \\
\hline Every other day & $113(17.2)$ & $105(16.0)$ & \\
\hline Once in a week & 127 (19.3) & $117(17.8)$ & \\
\hline Rare & $39(5.9)$ & $49(7.5)$ & \\
\hline \multicolumn{4}{|l|}{ Bakery Products } \\
\hline Never & $41(6.2)$ & $29(4.4)$ & \multirow{5}{*}{0.152} \\
\hline Everyday & $87(13.2)$ & $104(15.8)$ & \\
\hline Every other day & $65(9.9)$ & $67(10.2)$ & \\
\hline Once in a week & $71(10.8)$ & $67(10.0)$ & \\
\hline Rare & $74(11.3)$ & $52(7.9)$ & \\
\hline \multicolumn{4}{|l|}{ White Bread } \\
\hline Never & $110(16.7)$ & $79(12.0)$ & \multirow{5}{*}{$0.0001^{* *}$} \\
\hline Everyday & $100(15.2)$ & $152(23.1)$ & \\
\hline Every other day & $55(8.4)$ & $46(7.0)$ & \\
\hline Once in a week & $16(2.4)$ & $13(2.0)$ & \\
\hline Rare & $57(8.7)$ & $29(4.4)$ & \\
\hline \multicolumn{4}{|l|}{ Wholemeal Bread } \\
\hline Never & $42(6.4)$ & $101(15.4)$ & \multirow{5}{*}{$0.0001^{* *}$} \\
\hline Everyday & $164(25.0)$ & $96(14.6)$ & \\
\hline Every other day & $55(8.4)$ & $42(6.4)$ & \\
\hline Once in a week & $25(3.8)$ & $22(3.3)$ & \\
\hline Rare & $52(7.9)$ & $58(8.8)$ & \\
\hline \multicolumn{4}{|l|}{ Pasta-Rice } \\
\hline Never & $49(7.5)$ & $26(4.0)$ & \multirow{5}{*}{$0.046^{*}$} \\
\hline Everyday & $85(12.9)$ & $84(12.8)$ & \\
\hline Every other day & $93(14.0)$ & $100(15.2)$ & \\
\hline Once in a week & $63(9.6)$ & $75(11.4)$ & \\
\hline Rare & $48(7.3)$ & $34(5.2)$ & \\
\hline \multicolumn{4}{|l|}{ Fruits } \\
\hline Never & $14(2.1)$ & $14(2.1)$ & \multirow{5}{*}{$0.046^{*}$} \\
\hline Everyday & $186(28.3)$ & $152(23.1)$ & \\
\hline Every other day & $88(13.4)$ & $76(11.6)$ & \\
\hline Once in a week & $26(1.0)$ & $43(6.5)$ & \\
\hline Rare & $24(3.7)$ & $34(5.2)$ & \\
\hline \multicolumn{4}{|l|}{ Vegetables } \\
\hline Never & $5(0.8)$ & $12(1.8)$ & \multirow{5}{*}{0.163} \\
\hline Everyday & $172(26.2)$ & $162(24.7)$ & \\
\hline Every other day & $114(17.4)$ & $89(13.5)$ & \\
\hline Once in a week & $31(4.7)$ & $36(5.5)$ & \\
\hline Rare & $16(2.4)$ & $20(3.0)$ & \\
\hline \multicolumn{4}{|l|}{ Liquid Oil } \\
\hline Never & $20(3.0)$ & $6(0.9)$ & \multirow{5}{*}{0.085} \\
\hline Everyday & $208(31.7)$ & $198(30.2)$ & \\
\hline Every other day & $65(9.9)$ & $65(9.9)$ & \\
\hline Once in a week & $17(2.6)$ & $23(3.5)$ & \\
\hline Rare & $27(4.1)$ & $27(4.1)$ & \\
\hline \multicolumn{4}{|l|}{ Solid Fat } \\
\hline Never & 77 (11.7) & $82(12.5)$ & \\
\hline Everyday & $79(12.0)$ & $72(11.0)$ & \\
\hline Every other day & $65(9.9)$ & $62(9.4)$ & \\
\hline Once in a week & $32(4.9)$ & $30(4.6)$ & \\
\hline Rare & $85(13.0)$ & $73(11.1)$ & 0.8 \\
\hline
\end{tabular}

Table 4: The effect of health and diet related social media pages on the frequency of food consumption. 
According to the results of the frequency of food frequency questionnaire, those who follow health and diet related pages on social media consume significantly more dairy products ( $\mathrm{p}=0.031)$, wholemeal bread ( $\mathrm{p}=0.0001)$, fruit $(\mathrm{p}=0.046)$ and consume significantly less white bread $(\mathrm{p}=0.0001)$ and pasta-rice $(\mathrm{p}=0.046)$.
In table 5 , the effect of social media usage on participants' the body weight perceptions were shown. When the participants were separated according to their social media page follow-up status, no statistically significant difference was found between their body

\begin{tabular}{|c|c|c|c|c|c|c|}
\hline \multirow{2}{*}{$\begin{array}{l}\text { Following health and diet } \\
\text { related pages on social media }\end{array}$} & & \multicolumn{3}{|c|}{ Satisfaction with current body weight } & \multirow[b]{2}{*}{ TOTAL } & \multirow[b]{2}{*}{$\mathbf{p}$} \\
\hline & & $\begin{array}{c}\text { No body weight } \\
\text { problem }\end{array}$ & $\begin{array}{c}\text { Want to lose } \\
\text { weight }\end{array}$ & $\begin{array}{c}\text { Want to gain } \\
\text { weight }\end{array}$ & & \\
\hline \multirow[t]{7}{*}{ Yes } & & & BMI & & & \multirow{12}{*}{$p>0.05^{+}$} \\
\hline & Thin & $4(1.2)$ & $0(0.0)$ & $7(2.1)$ & $11(3.3)$ & \\
\hline & Normal & $116(34.7)$ & $78(23.4)$ & $27(8.1)$ & $221(66.2)$ & \\
\hline & Overweight & $19(5.7)$ & $62(18.6)$ & $2(0.6)$ & $83(24.9)$ & \\
\hline & Obese & $0(0.0)$ & $19(5.7)$ & $0(0.0)$ & $19(5.7)$ & \\
\hline & TOTAL & $139(41.6)$ & $159(47.6)$ & $36(10.8)$ & $334(100.0)$ & \\
\hline & & & BMI & & & \\
\hline \multirow[t]{5}{*}{ No } & Thin & $3(0.9)$ & $0(0.0)$ & $10(3.1)$ & $13(4.1)$ & \\
\hline & Normal & $114(35.8)$ & $54(17.0)$ & $37(11.6)$ & $205(64.5)$ & \\
\hline & Overweight & $15(4.7)$ & $47(14.8)$ & $3(5.9)$ & $65(20.4)$ & \\
\hline & Obese & $0(0.0)$ & $34(20.7)$ & $1(0.3)$ & $35(11.0)$ & \\
\hline & TOTAL & $132(41.5)$ & $135(42.5)$ & $51(16.0)$ & $318(100.0)$ & \\
\hline
\end{tabular}

Table 5: Effect of social media on body weight perception.

+ Significance test was applied for each categorical group. No significant difference was found between any categorical data.

weight perceptions and their desire to lose or gain weight according to their BMIs ( $p>0.05)$.

\section{Discussion}

Media, which is widely used today, can affect people's thoughts about healthy nutrition. People's perceptions of there body image can be influenced by media and can direct them to sports in order to reach their ideal body perception. The increased prevalence of dieting, especially in young girls, is related to the differences between actual body weight and the body weight which is perceived as ideal, due to body changes that start during puberty. The reasons for this are the desire to be slim, the social norms related to the appearance and the effect of the mass media [14]. It was found in a study conducted in USA, one-third of individuals use social media to get information about health, almost all of them get information about health professionals using social media [15]. According to the Household Information Technology Usage Survey data from Turkey Statistical Institute in 2016, among the objectives of people using the Internet, search for information about health ranks fourth with $65.9 \%$ [16]. According to a research conducted in Turkey, articles about nutrition in 7 newspapers were examined and only $27 \%$ of them were found to contain scientific information [17]. As shown in Table 3, in this study, while the sources in which men and women obtained nutritional information were similar, internet $(21.2 \%$ of women and $27.9 \%$ of men) was the first source of information in both sexes $(p>0.05)$. However, it was found that women $(21.5 \%)$ followed more health and diet related acounts on social media compared to men $(17.1 \%)(\mathrm{p}=0.0001)$, and that women changed their nutritional habits according to these social media acounts when compared to men ( $\mathrm{p}=0.024)$.

The development of technology, the spread of social media, industrialization, increasing education level, economic and social welfare have increased people's interest in food and healthy nutrition. Conscious nutrition has become not only the area of interest of the society but also the concern of being popular and this has increased the number of explanations and news about the food in the media. Incorrect statements made by people who do not have access to real, quality, healthy and sufficient information can cause confusion for the consumer [18].

Comparing the diet page follow-up status and the change in dietary habits of the individuals who participated in this study (Table 4), it was found that those who followed these pages consume statistically more dairy products $(p=0.031)$, wholemeal bread $(p=0.0001)$ and fruit $(p=0.046)$ while consuming less white bread $(p=0.0001)$ and pasta-rice $(p=0.046)$.

Since mass media, close friends and families are known to have an effect on the body perception, it is not surprising that several studies have found that social media is effective on body perception [19]. Although some effects of social media use are universal, 
the degree to which individuals are affected by social media use may vary across cultures [20]. Very few studies have examined the effect of the use of social media on people's body perception. In our study, when the participants were separated according to their social media page follow-up status, no statistically significant difference was found between their body perceptions and their desire to lose or gain weight according to their BMIs.

It is still controversial whether social media is effective in encouraging individuals in diet and physical activity [21]. In contemporary digital technology and social media which is an inseparable part of our lives, some attitudes and body image concerns can be developed and transferred to conviction [22]. Therefore, further studies and investigations are needed in this area.

\section{Conclusion}

In this study that was conducted with individuals who attend sports centers, we investigated the effect of media and sports on nutritional habits. There are not many studies on this subject in the literature. It is a surprising conclusion that women and men who do sports obtain their nutritional information from the internet. Moreover, women are more likely to change their nutritional habits more often according to information they obtain from the internet as compared to men. Nowadays, the widespread use of the internet, and especially social media and the high level of nutritional information pollution these channels produce, may lead to misinformation. The presence of a dietitian in sports centers and the efforts of these dietitians to give proper nutrition information can prevent such problems.

\section{Bibliography}

1. Maher CA., et al. "Are health behavior change interventions that use online social networks effective? A systematic review". Journal of Medical Internet Research 16.2 (2014): 40.

2. Kartal N and Erigüç G. "Sağllk Iletişiminde Bir Unsur Olarak Sosyal Medya: Bir Sosyal içerik Platformundaki Sağlık Haberlerinin Incelenmesi (Sosyal Social Media as an Aspect in Health Communication: Investigation of Health News on a Social Content Platform)". Gumushane University Faculty of Communication Electronic Journal 6.1 (2018): 570.

3. Noar SM. "A 10-year retrospective of research in health mass media campaigns: where do we go from here?" Journal of Health Communication 11.1 (2006): 21-42.

4. Bennett GG and Glasgow RE. "The delivery of public health interventions via the Internet: actualizing their potential". Annual Review of Public Health 30 (2009): 273-292.

5. Fergie G., et al. "Young adults' experiences of seeking online information about diabetes and mental health in the age of social media". Health Expectations 19 (2016): 1324-1335.
6. Aktaş N and Cebirbay MA. "Tüketicilerin Beslenme Bilgilerine Erişmede Kullandıkları Kitle İletişim Araçları Üzerine Bir Araştırma (A Research on Mass Media Used by Consumers to Access Nutritional Information)". Journal of Black Sea Social Sciences 11 (2003): 49.

7. Gunter RB., et al. "Physical Activity and Body Image Among Men and Boys: A Meta-Analysis". Body Image 22 (2017): 114128.

8. Öngören B. "Sosyolojik Açıdan Sağlıklı Beden İmgesi (Sociologically Healthy Body Image)". Journal of Social and Humanities Research 34 (2015): 30.

9. Oran NT., et al. "Medyanın Kadınların Beslenme Alışkanlıkları, Besin Seçimi ve Tüketimi Üzerindeki Etkileri (Effects of Media on Women's Nutritional Habits, Food Selection and Consumption)". Life Sciences 12 (2017): 2.

10. Ceylan C., et al. "Konya'da Spor Salonlarına Devam Eden Kadınlarda Beslenme Alışkanlıklarının Belirlenmesi (Determination of Nutritional Habits of Women Attending Gyms in Konya)". International Refereed E-Journal of Social Sciences 70 (2018): 89.

11. Ata A., et al. "Beden Algisı ve Obezite (Body Perception and Obesity)". Ankara Medical Journal 14 (2014): 75.

12. Pehlivan Z., et al. "Ev Kadınlarının Sosyal Görünüş Kaygıları ve Sağlıklı Yaşam Biçimi Davranışları (Social Appearance Anxiety and Healthy Lifestyle Behaviors of Housewives)". Journal of Sport Sciences 28 (2017): 12.

13. WHO (World Health Organization).

14. Lindwall M. "The role of exercise and gender for physical selfperceptions and importance rating in Swedish university students". Scandinavian Journal of Medicine and Science in Sports 14 (2014): 373-380.

15. Wu T., et al. "The Effect of Doctor-Consumer Interaction on Social Media on Consumers' Health Behaviors: Cross-Sectional Study". Journal of Medical Internet Research 20 (2018): 2.

16. TÜIKK (Turkish Statistical Institute). "Hane Halkı Bilişim Teknolojileri Kullanım Araştırması (Household Information Technology Use Survey)" (2016).

17. Aksoydan E., et al. "Medya Kadınları Beslenme Konusunda Nasıl Etkiliyor? (How Media Affects Women on Nutrition?)". Journal of Continuing Medical Education 19 (2010): 1-5.

18. Helm J and Jones RM. "Practice Paper of The Academy of Nutrition and Dietetics: Social Media and The Dietetics Practitioner: Opportunities, Challenges and Best Practices". Journal of The American Academy of Nutrition and Dietetics 116 (2016): 1825-1835. 
19. Burns KS. "Celeb 2.0: How social media foster our fascination with popular culture”. ABC-CLIO. Santa Barbara, CA: Praeger (2009).

20. Hye-Ryeon L., et al. "Social Media Use, Body Image, and Psychological Well-Being: A Cross-Cultural Comparison of Korea and the United States". Journal of Health Communication 19 (2014): 1343-1358.

21. Duman AA., et al. "Users, Uses, and Effects of Social Media in Dietetic Practise: Scoping Review of the Quantitative and Qualitative Evidence". Journal of Medical Internet Research 20 (2018): 10.

22. Perloff RM. “Social Media Effects on Young Women's Body Image Concerns: Theoretical Perspectives and an Agenda for Research". Sex Roles 71 (2014): 363.

\section{Volume 3 Issue 12 December 2019}

(C) All rights are reserved by Ayse Humeyra Islamoglu., et al. 